\title{
Sistem Pengenalan Spesifikasi Mobil pada Showroom Berbasis Haar-Like Features
}

\author{
http://dx.doi.org/10.28932/jutisi.v6i3.2903 \\ Andrew Sebastian Lehman ${ }^{\# 1}$, Joseph Sanjaya ${ }^{\bowtie * 2}$ \\ \#Jurusan Sistem Komputer, Universitas Kristen Maranatha \\ Jl. Surya Sumantri No.65, Sukawarna \\ *Jurusan Magister Ilmu Komputer, Universitas Kristen Maranatha \\ Jl. Surya Sumantri No.65, Sukawarna \\ ${ }^{1}$ andrewsebastianlegmail.com

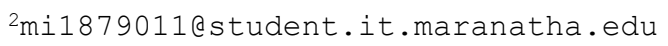

\begin{abstract}
Changes in science and technology have affected the structure of societies and have led to rapid changes in human profiles. In order to adapt to the changing human profile, reforms in advertising, as well as scientific and technological enrichment in advertisement environments, have become necessary. This study aims to investigate the impact of advertisement materials developed with augmented reality (AR) technology on car specification presentation and attitudes towards the advertisement, and to determine their attitudes towards AR applications. In this study, AR application was developed using Haar-Like features method for marker detector. A quasi-experimental design was used in which intact showrooms at two different locations, consisting of a total of one hundred customers, were randomly assigned to either the experimental or control group. The experimental group researched their selected car using AR technology, while the control group researched their selected car using traditional methods and the help of salesmen. Customers in the experimental group were found to have a higher understanding and slightly faster to learn about the car than those in the control group. In addition, the results revealed that the customers were pleased and wanted to continue using AR applications in the future. They also showed no signs of anxiety when using AR applications. In addition, it was found that advertisement achievements and attitudes of the customers in the experimental group showed a positive, significant, and intermediate correlation.
\end{abstract}

Keywords - Augmented Reality; Car Specification; Haar-like features; Advertisement; Marker Detector

\section{Pendahuluan}

\section{A. Latar Belakang}

Dewasa ini perkembangan teknologi semakin pesat, sehingga kehidupan manusia sudah banyak dibantu oleh berbagai mesin vision. Sudah banyak bidang yang diintegrasikan ke dalam bentuk vision sehingga tidak lagi hanya konsep yang membutuhkan waktu yang cukup lama untuk dijelaskan. Terutama dalam bidang objek marketing yang memiliki spesifikasi yang kompleks seperti otomotif mobil. Seringkali sales mobil kesulitan dalam menjelaskan spesifikasi barang yang dijualnya karena tanpa bantuan gambaran vision spesifikasi mobil sulit untuk dibayangkan. Hal ini menyebabkan banyaknya waktu terbuang dan membuat perusahaan untuk memperkerjakan lebih banyak orang [1].

Berdasarkan kenyataan tersebut dibuatlah software untuk membantu penjelasan spesifikasi mobil dengan menggunakan teknologi $A R$. Grafik yang dihasilkan dirancang sedemikian rupa sehingga mudah untuk dilihat dan dipelajari. Cara kerja software ini adalah dengan membaca gambar yang telah dimasukkan ke dalam dataset, lalu memakai image processing berdasarkan metode haarlike features untuk mengenali gambar yang telah ditentukan.

\section{B. Rumusan Masalah}

Berikut ini merupakan 2 hal yang menjadi fokus permasalahan utama:

a. Pembuatan aplikasi $A R$ menggunakan metode haarlike features sebagai marker detector.

b. Perbedaan respon terhadap penjelasan spesifikasi mobil yang dilakukan secara tradisional dan menggunakan aplikasi berbasis $A R$.

\section{Tujuan}

Tujuan dilakukannya penelitian ini antara lain:

a. Merancang aplikasi pengenalan spesifikasi mobil berbasis $A R$ menggunakan metode haar-like features.

b. Menganalisis efektifitas metode haar-like features dalam aplikasinya terhadap aplikasi berbasis $A R$.

c. Menganalisis respon kustomer terhadap pengenalan spesifikasi mobil menggunakan aplikasi $A R$. 


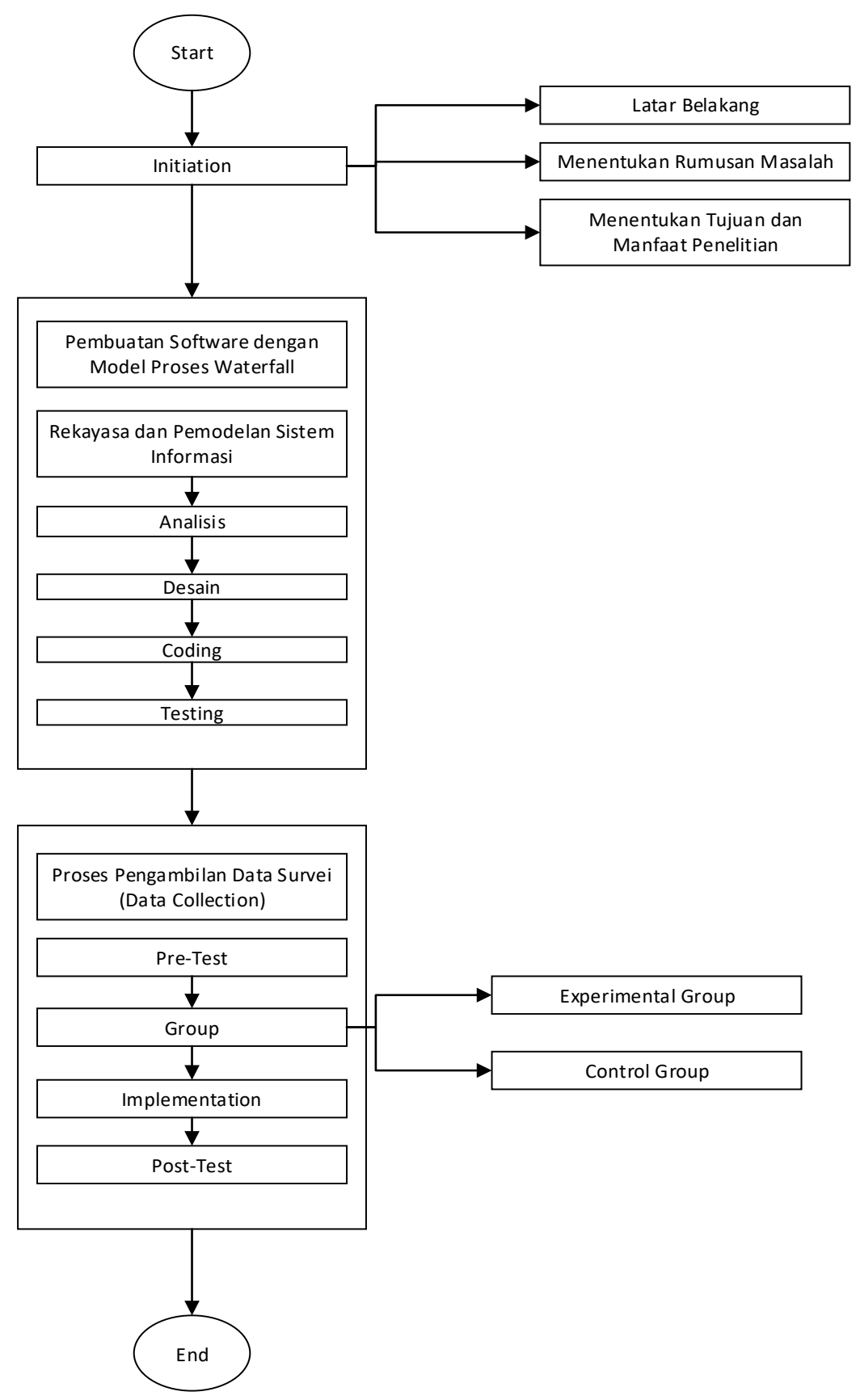

Gambar 1. Tahapan Penelitian

\section{Desain Penelitian}

Desain dari penelitian ini dideskripsikan dengan diagram flowchart yang dapat dilihat pada gambar 1. Berikut merupakan penjelasan dari setiap tahap penelitian:

\section{Initiation}

Tahap pertama dalam penelitian ini adalah inisiasi dengan melakukan beberapa langkah sebagai berikut:

a. Latar Belakang
Memaparkan latar belakang dilakukannya penelitian.

b. Menentukan Rumusan Masalah

Menemukan dan merumuskan pertanyaan penelitian yang akan dilakukan sebagai solusi atas permasalahan yang dipaparkan pada latar belakang penelitian.

c. Menentukan Tujuan dan Manfaat Penelitian

Menentukan tujuan dari solusi yang akan diteliti terhadap permasalahan dan pihak yang akan 
diuntungkan.

d. Kerangka Pemikiran

Memaparkan kerangka pemikiran awal penelitian.

2. Pembuatan Software dengan Model Proses Waterfall

Metode ini mengusulkan pendekatan pada masalah software yang sistematik dan sekuensial dengan tahap sebagai berikut:

a. Rekayasa dan Pemodelan Sistem Informasi

Perumusan hal-hal yang akan diimplementasikan ke dalam sistem (hardware, software dan lainnya).

b. Analisis

Pengumpulan sumber-sumber data pendukung penelitian, penyusunan waktu penelitian dan penguraian tools yang digunakan.

c. Desain

Perancangan representasi dari aplikasi.

d. Coding

Penterjemahan desain ke dalam bahasa yang dapat dibaca.

e. Testing

Pengujian tiap modul yang terdapat dalam sistem, perbaikan modul apabila terjadi ketidaksesuaian hasil yang diharapkan.

\section{Proses Pengambilan Data Survei (Data Collection)}

a. Pre-Test

Mempersiapkan bahan yang akan digunakan untuk diberikan kepada responden.

b. Group

Melakukan pengelompokan responden ke dalam 2 group yaitu:

c. Experimental Group

Merupakan group yang akan menggunakan teknologi $A R$ dalam pemilihan mobil.

d. Control Group

Merupakan group yang menggunakan cara konvensional dalam pemilihan mobil.

e. Implementation

Mengumpulkan hasil implementasi penelitian dari kedua group.

f. Pre-Test

Melakukan analisis terhadap hasil implementasi penelitian dari kedua group.

\section{KAJIAN LITERATUR}

\section{A. Penelitian Serupa}

$A R$ merupakan topik penting dalam bidang visi komputer yang telah banyak diteliti. Berbagai algoritma telah diusulkan dari berbagai peneliti berdasarkan fitur yang berbeda atau pengklasifikasi yang berbeda. Aiwen Luo mengusulkan penggunaan algoritma haar-like features dan SVM classifier untuk menghasilkan Model pendeteksi yang bersifat hardware efficient [2]. Daniel Lima Gomes mengusulkan penggunaan haar-based dalam pendeteksi natural marker untuk augmented visualization pada power systems substations [3]. Tasneem Khan dan Dilara Shain meneliti dampak penggunaan aplikasi berbasis $A R$ terhadap pelajaran untuk siswa yang melingkupi pencapaian, perilaku, dan motivasi siswa [4, 5]. Chunhua Shen meneliti efektivitas training pada node classifier ada cascade classification [6]. Niamh Conway melakukan penelitian terhadap dampak aplikasi berbasis $A R$ terhadap participatory marketing [7].

\section{B. Immersive Technology}

Immersive Technology adalah teknologi yang memperluas realitas atau menciptakan realitas baru dengan memanfaatkan ruang 360. Karena Immersive Technology memanfaatkan ruang 360 , pengguna dapat melihat ke segala arah dan melihat konten. Beberapa jenis Immersive Technology memperluas kenyataan dengan melapisi gambar digital pada lingkungan penggunanya. Ada juga yang menciptakan kenyataan baru yang menutupi pandangan pengguna terhadap dunia nyata. Gambar 2 menggambarkan proses yang terjadi pada Immersive Technology [8].

\section{Tipe Immersive Technology}

Jenis-jenis Immersive Technology adalah 360, VR, AR, $M R$, dan $X R$ :

a. 360

360 adalah Immersive Technology paling dasar dan mungkin paling dikenali di luar sana. Konten 360 memungkinkan pengguna menjelajahi konten dengan melihat ke segala arah $(360 \%$ Sphere $)$.

b. Virtual Reality (VR)

Virtual Reality adalah jenis lain dari Immersive Technology yang sangat terkenal. Melalui HMD (Head Mounted Display), konten apa pun yang dialami pengguna di headset menjadi "kenyataan" memungkinkan pengguna untuk mengalami dunia virtual seolah-olah benar-benar nyata [9].

c. Augmented Reality (AR)

Augmented Reality $(A R)$ adalah jenis berbeda Immersive Technology di mana gambar digital ditampilkan di atas dunia nyata.

d. Mixed Reality $(M R)$

Mixed Reality $(M R)$ merupakan kombinasi dari $A R$ dan $V R$. Seperti $V R, M R$ juga menggunakan $H M D$ (Head Mounted Display), tetapi pengguna tidak diasingkan dari dunia nyata. Sebaliknya, HMD (Head 


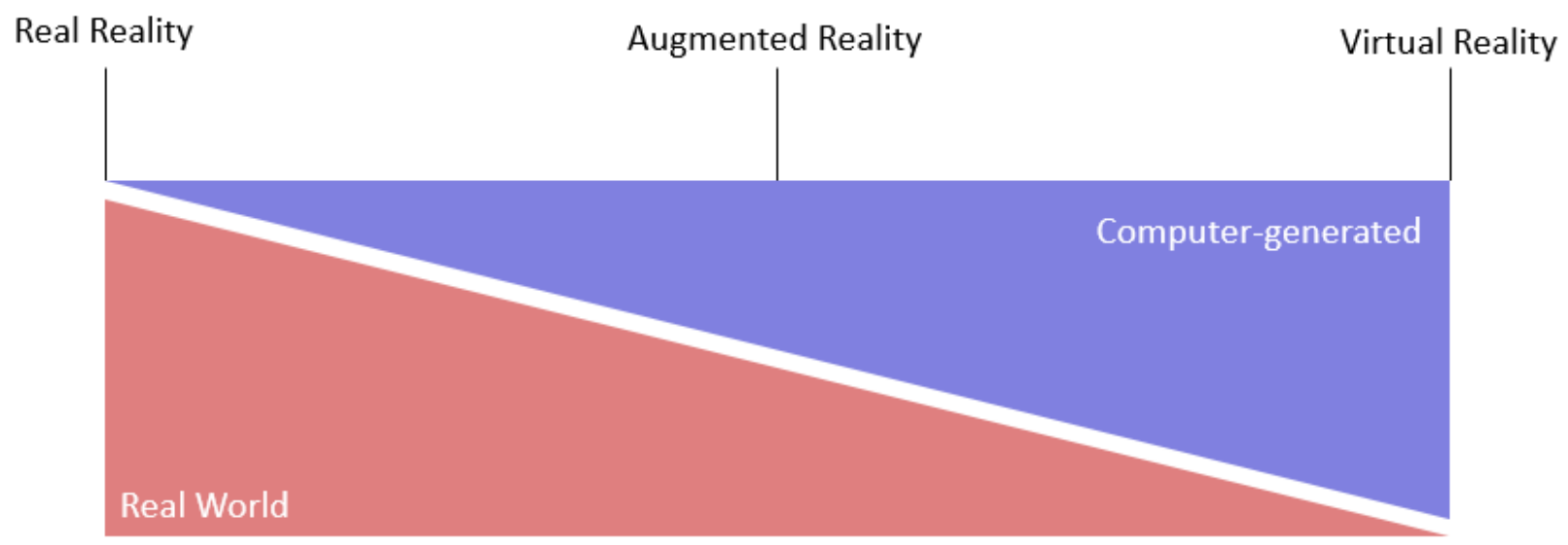

Gambar 2. Immersive Computing Spectrum

Mounted Display) dipakai sebagai sepasang kacamata yang menampilkan gambar digital di atas lingkungan pengguna [10].

e. Extended Reality $(X R)$

Extended reality $(X R)$ adalah istilah yang mengacu pada semua lingkungan gabungan nyata, virtual, dan interaksi manusia dan mesin yang dihasilkan oleh teknologi komputer dan perangkat yang dapat dikenakannya. Hal ini termasuk bentuk-bentuk representatif seperti Augmented Reality (AR), Mixed Reality $(M R)$, dan Virtual Reality $(V R)$.

\section{Augmented Reality}

Augmented reality adalah cara melihat dunia nyata (baik secara langsung atau melalui perangkat seperti kamera) dengan "menambahkan" visual dunia nyata dengan input yang dihasilkan komputer seperti grafik, audio, atau video [11]. Teknologi ini dapat menipiskan batas antara objek yang nyata dan objek yang dihasilkan komputer sehingga dapat dilihat, didengar, dirasa bahkan dicium. Sebagai contohnya, apabila berjalan atau mengemudi di jalan, dengan Augmented Reality, elemen-elemen digital grafis akan muncul di bidang yang dipandang, seperti pada kacamata atau pada kaca depan mobil.

Kemudian ketika membaca koran, dengan Augmented Reality koran tersebut tidak hanya menampilkan tulisan dan foto, tetapi dapat juga melihat video dan mendengar suara yang keluar melalui koran tersebut.

Augmented Reality sebagai penggabungan benda-benda nyata dan maya di lingkungan nyata, berjalan secara interaktif dalam waktu nyata (realtime), dan terdapat integrasi antar benda dalam tiga dimensi, yaitu benda maya terintegrasi dalam dunia nyata [12]. Penggabungan benda nyata dan maya dimungkinkan dengan teknologi tampilan yang sesuai, interaktivitas dimungkinkan melalui perangkat- perangkat input tertentu [13].

Definisi Augmented Reality (AR) dalam bahasa Indonesia adalah realitas tertambah, teknologi yang menggabungkan benda maya dua dimensi dan ataupun tiga dimensi ke dalam sebuah lingkungan nyata tiga dimensi lalu memproyeksikan benda-benda maya tersebut dalam waktu nyata. Bendabenda maya berfungsi menampilkan informasi yang tidak dapat diterima oleh manusia. Hal ini membuat Augmented Reality berguna sebagai alat untukmembantu persepsi dan interaksi penggunanya dengan dunia nyata. Informasi yang ditampilkan oleh benda maya membantu pengguna melaksanakan kegiatan-kegiatan dalam dunia nyata [14].

\section{E. Haar-like features}

Features selection adalah masalah penting dalam konteks pengenalan objek. Fitur yang sesuai dapat mempertahankan atribut asli piksel kasar dari sensor gambar dalam scenes aplikasi yang diinginkan. Haar-like features yang digunakan dalam makalah ini mengingatkan pada fungsi dasar Haar [15], yang dilaporkan pada penelitian yang dlilakukan oleh Viola dan rekannya [16], dan dikenal memiliki kelebihan dalam mengurangi kompleksitas pencocokan objek serta meningkatkan kinerja komputasi. Khususnya, perbedaan antara jumlah piksel yang berdekatan dalam dua bidang persegi panjang (lihat A dan B pada Gambar 3) lebih dari 4 $\times 4$ piksel grid (dinamai sub-sel) dari lokasi spasial dalam arah horisontal atau vertikal dihitung sesuai dengan rumus (1) atau (2) [11].

$$
\begin{aligned}
& D_{x}=\sum_{p(x) \in A} p(x)-\sum_{p(x) \in B} p(x), \\
& D_{y}=\sum_{p(y) \in A} p(y)-\sum_{p(y) \in B} p(y) .
\end{aligned}
$$

Namun dikarenakan pembacaan bergantung pada intensitas gambar, yang berarti nilai piksel $R G B$ di setiap piksel pada gambar, membuat perhitungan fitur berat secara 
komputasi dan menyebabkan kelambatan pada kebanyakan

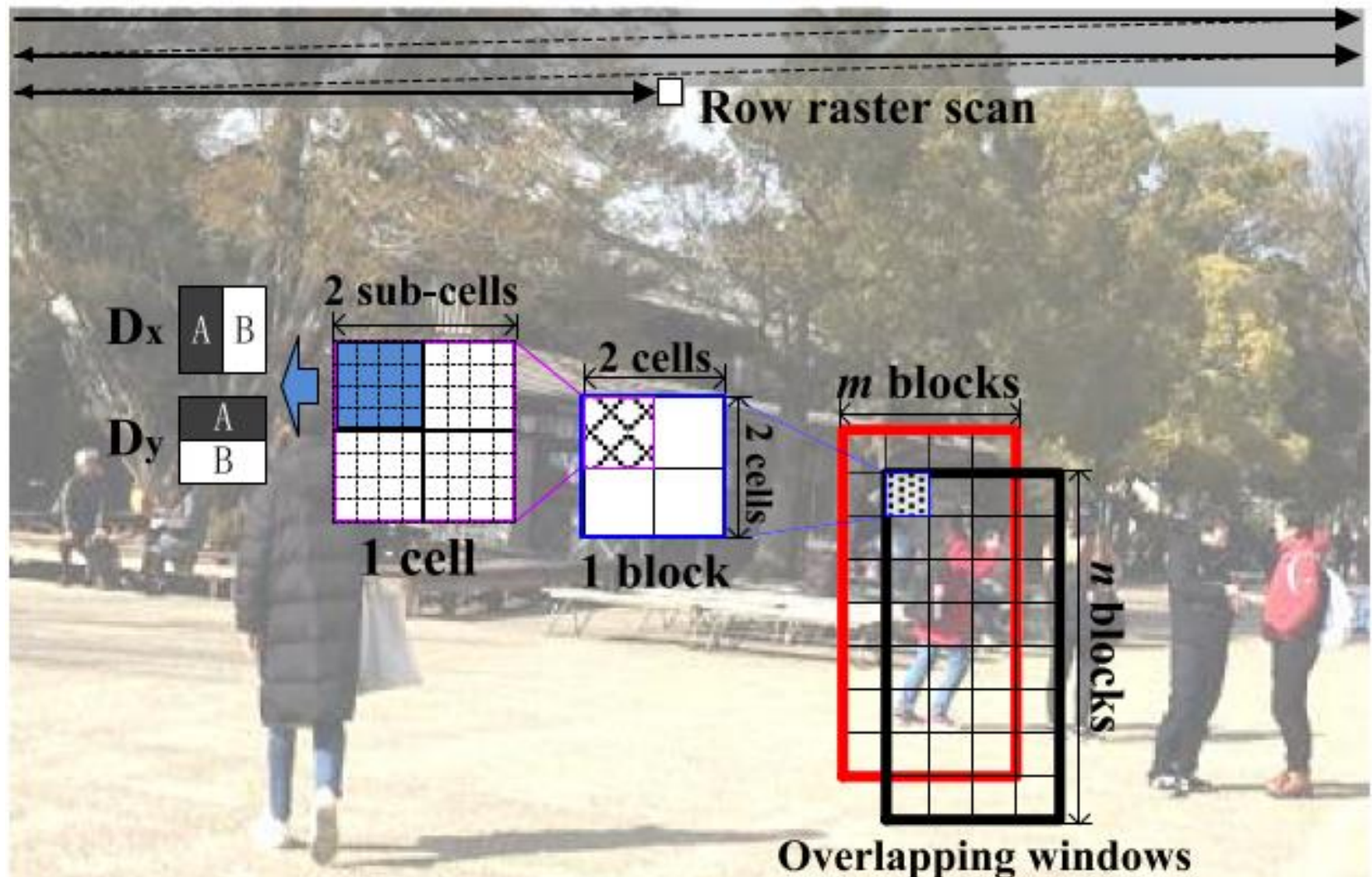

Gambar 3. Pemindaian dan pemetaan hubungan antar sub-sel

platform. Masalah ini dapat ditangani oleh Haar-like features. Haar-like features mempertimbangkan daerah persegi panjang di sekitar lokasi tertentu pada jendela deteksi, meringkas intensitas piksel di masing-masing daerah dan menghitung selisih antara jumlah piksel tersebut [17]. Perbedaan ini kemudian digunakan untuk mengkategorikan bagian-bagian gambar. Proses ini dapat dilihat pada gambar 4 .

\section{Edge features}

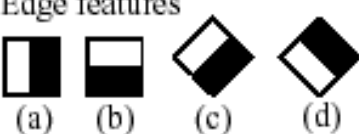

2. Line features
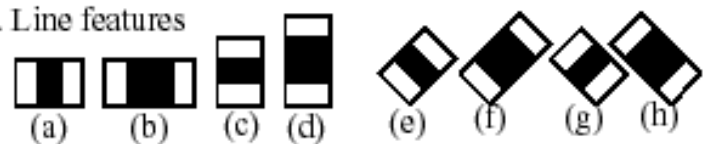

3. Center-surround features
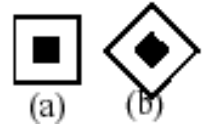

Gambar 4. Haar-like features
Contoh dari hal ini adalah deteksi wajah manusia. Biasanya, area di sekitar mata lebih gelap dari area di pipi. Salah satu contoh Haar-like features untuk deteksi wajah adalah satu set dari dua area persegi empat di atas daerah mata dan pipi.

\section{F. Cascade Classifier}

Cascade Classifier terdiri dari daftar tahap, system akan terus berkembang setiap melalui satu tahap. System mendeteksi objek yang dimaksud dengan memindahkan jendela ke atas gambar [2]. Setiap tahap dari Classifier memberi label pada wilayah spesifik yang didefinisikan oleh lokasi jendela sebagai positif atau negatif. Positif yang berarti bahwa benda ditemukan atau negatif berarti objek yang ditentukan tidak ditemukan pada gambar. Jika pelabelan menghasilkan hasil yang negatif, maka klasifikasi wilayah spesifik ini selesai dan lokasi jendela dipindahkan ke lokasi berikutnya. Jika pelabelan memberi hasil positif, maka wilayah tersebut bergerak ke tahap klasifikasi selanjutnya. Classifier menghasilkan keputusan akhir yang positif, ketika semua tahap mengatakan bahwa objek tersebut ditemukan pada gambar [16]. Proses dapat dilihat 
pada gambar 5 .

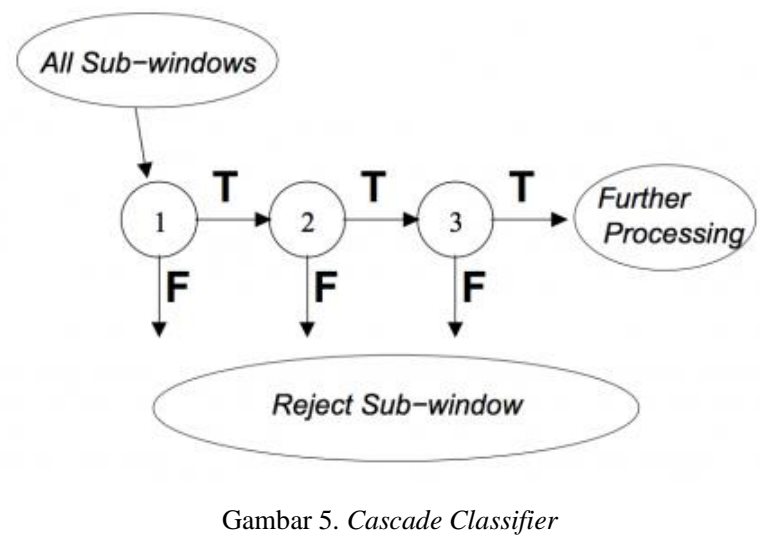

III. PERANCANGAN

\section{A. Flowchart Utama 1}

Pada subbab ini akan dijelaskan flowchart inisialisasi dari software Augmented ini, flowchart tersebut dapat dilihat pada gambar 6 .

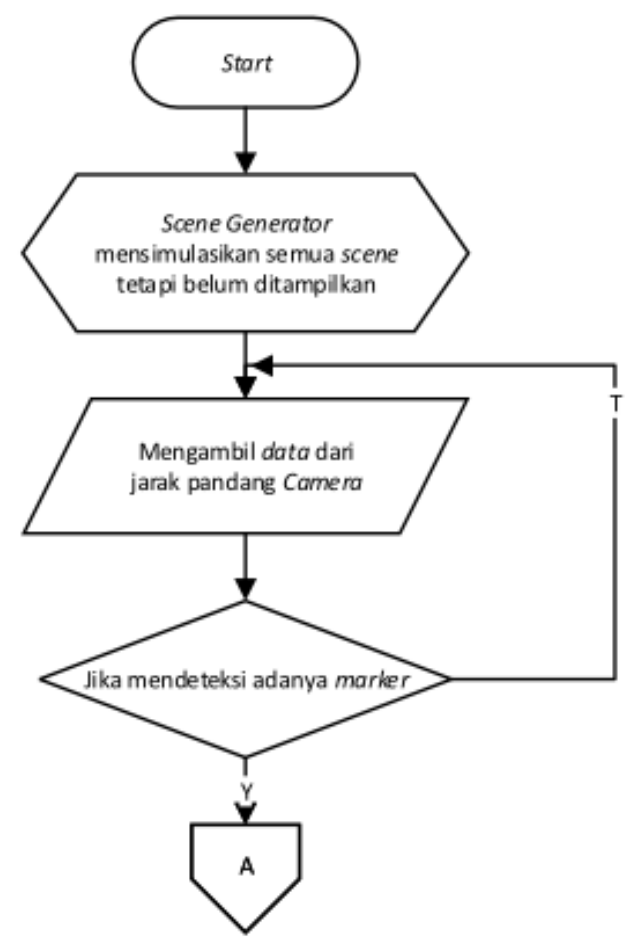

Gambar 6. Flowchart Utama 1

Gambar 6 merupakan flowchart yang menjelaskan scene generator yang mensimulasikan scene untuk setiap Model yang akan ditampilkan setelah mendeteksi adanya marker. Setelah inisialisasi tersebut, Aplikasi Android menarik data dari camera sebagai indikator ada atau tidaknya marker.
Jika Aplikasi Android mendeteksi adanya marker maka akan berlanjut ke proses selanjutnya, jika tidak maka Aplikasi Android akan mengambil data terus menerus dari camera.

\section{B. Flowchart Utama 2}

Pada subbab ini akan dijelaskan flowchart proses dari software Augmented ini, flowchart tersebut dapat dilihat pada gambar 7. Gambar 7 merupakan flowchart yang menjelaskan data yang diambil dari dataset dikomparasi dengan data marker yang didapat dari camera. Pada segment flowchart ini, dijelaskan adanya 5 jenis data spesifikasi mobil pada dataset dan 5 jenis data marker pada camera. Jika saat dikomparasi menghasilkan hasil true pada salah satu data maka scene yang mengandung spesifikasi yang bersangkutan akan dipanggil dan ditampilkan pada display dan jika tidak maka akan dicek terus menerus.

\section{Perancangan Proyeksi 3D}

Dalam proses pembuatan representasi spesifikasi yang jelas dengan bidang $3 D$, terutama yang akan digunakan pada Augmented Reality, dibutuhkan referensi yang jelas dan memiliki informasi yang dapat mudah dimengerti oleh pengguna. Dalam bab ini akan dilihat alur kerja yang digunakan untuk menciptakan informasi ini [18]. Proyeksi 3D ini akan dibuat menggunakan Blender. Langkah-langkah yang dilakukan pada Blender, antara lain:

a. Inisiasi

Hal pertama yang perlu dilakukan untuk mengembangkan $3 D$ Model pada Blender yaitu pengembang harus membuat new scene terlebih dahulu.

b. Gambar Referensi

Gambar referensi dibutuhkan sebagai referensi pengembang dalam membentuk mesh, hal ini diperlukan jika ingin membuat photorealistic graphics. Gambar referensi dapat ditambahkan melalui 3D View Properties. 3D View Properties dapat ditampilkan dengan melakukan klik pada tanda + dibagian kanan atas $3 D$ View dan melakukan drag ke arah kiri.

c. Membentuk Base Mesh

Dimulai dari default mesh kubus sederhana, 3D Model dibentuk berdasarkan gambar referensi. Pembentukan mesh biasanya dimulai dengan menambahkan object mesh dalam Object Mode.

d. Membuat $U V$ Wrapping Map

Dalam melakukan proses ini, pengembang dapat mengubah Screen Layout pada Blender menjadi $U V$ Editing agar mempermudah pembuatan UV Map. Pembuatan $U V$ Map hanya dapat dilakukan pada saat keadaan Edit Mode. 
e. Membuat Tekstur berdasarkan UV Map

Setelah $U V$ Map dibuat, tekstur dirancang

tekstur pada software ini dibuat menggunakan Adobe berdasarkan gambar $U V$ Map tersebut. Pembuatan

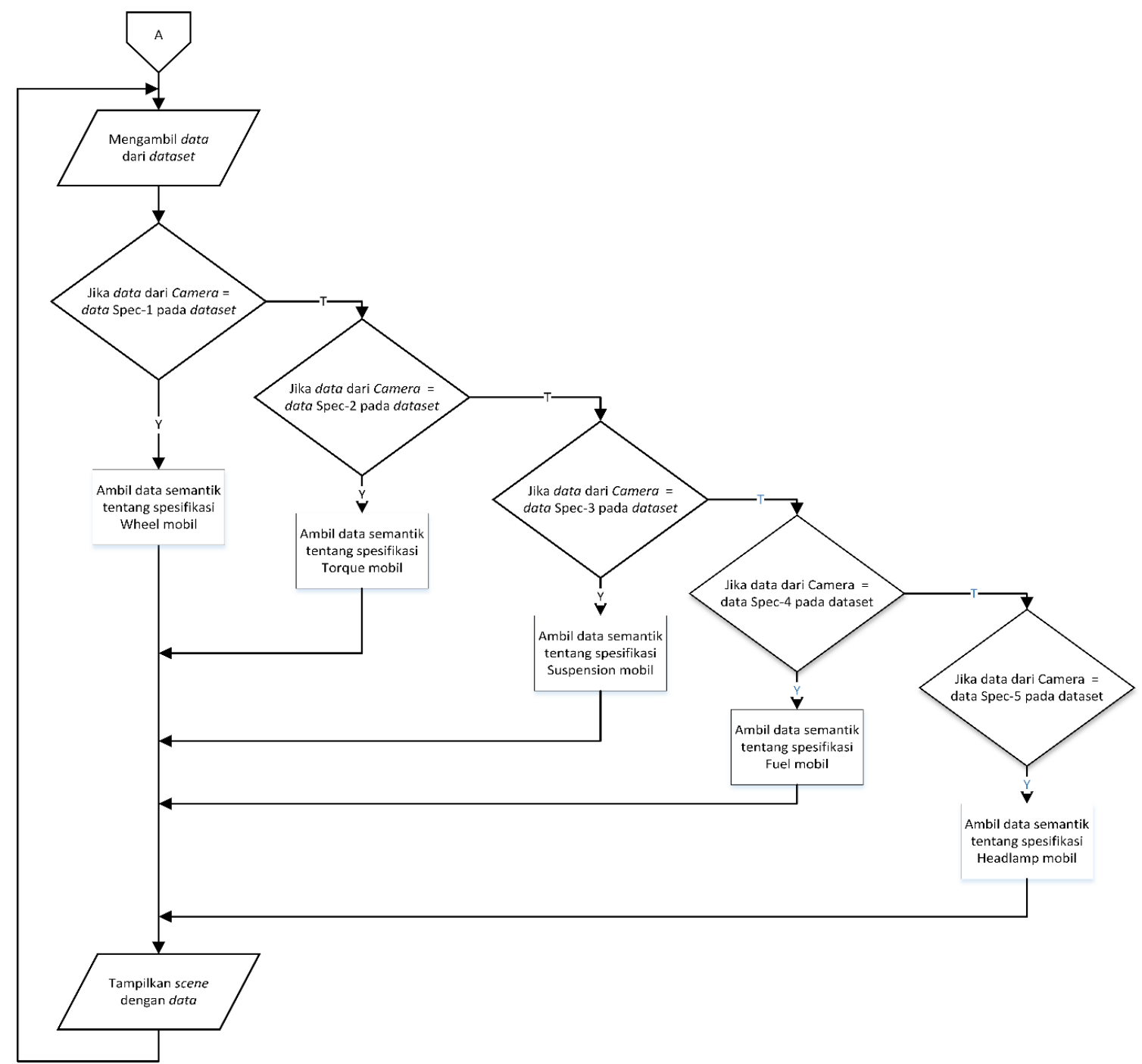

Gambar 7. Flowchart Utama 2

f. Membuat Materials

Dalam grafik komputer, Materials adalah peningkatan pemetaan tekstur (dan prasyarat untuk efek bayangan canggih) yang memungkinkan object dalam Pemodelan $3 D$ dan video games untuk mensimulasikan berbagai jenis bahan dalam kehidupan nyata. Materials biasanya digunakan untuk meningkatkan realisme mesh poligon dan data $3 D$ model.

Hasil proyeksi pada Viewport dapat dilihat pada gambar 8.

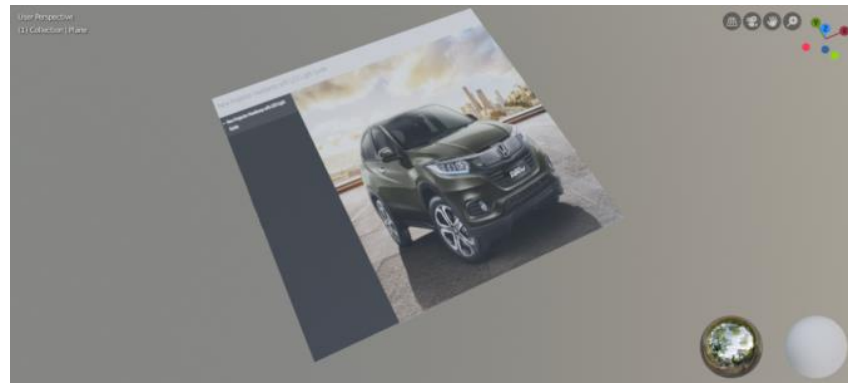

Gambar 8. Hasil Proyeksi pada Viewport

\section{Pembuatan Marker}

Gambar yang akan digunakan sebagai marker harus memiliki perbedaan warna yang kontras sehingga dapat 
dengan mudah dibedakan dengan gambar lainnya. Semakin kompleks gambar maka akan semakin mudah dibaca oleh software yang dibuat. Untuk pembuatan gambar marker digunakan software Photoshop. Proses pembuatan gambar dapat dilihat pada gambar 9 .

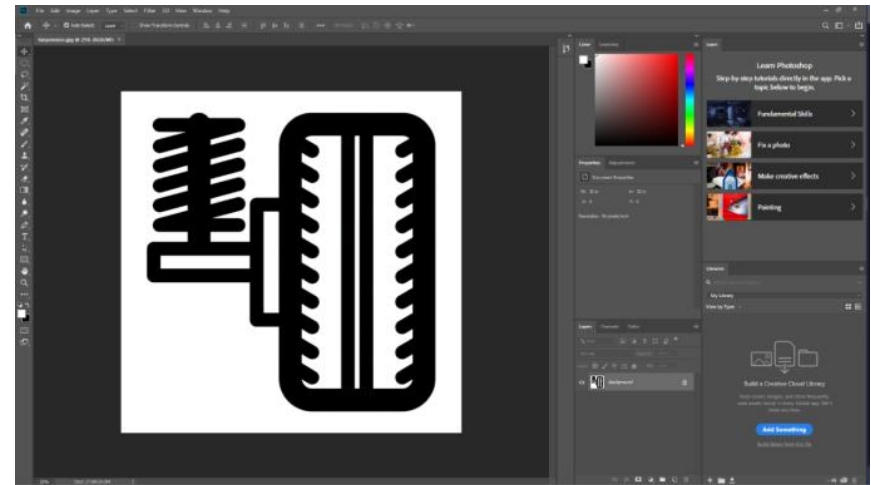

Gambar 9. Proses Pembuatan Marker dengan Menggunakan Aplikasi Photoshop

\section{E. Pembacaan Marker}

Setelah gambar dibuat maka keunikan gambar dibaca menggunakan Haar-like features dan Cascade Classifier. Menghasilkan titik-titik unik yang dijadikan indikator oleh software untuk menampilkan scene $3 D$ nantinya. Hasil pembacaan dapat dilihat dengan tanda titik kuning pada gambar 10 .

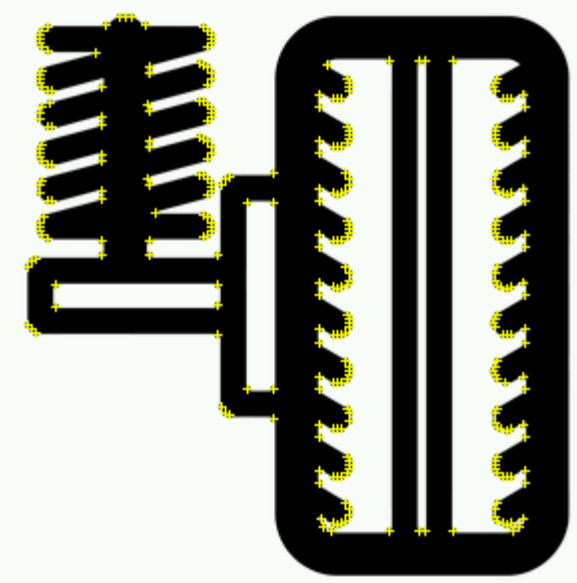

Gambar 10. Hasil Ekstraksi Fitur terhadap Marker

\section{F. Integrasi Marker Detection pada Camera}

Pada aplikasi Unity, untuk menambahkan komponen baru sebagai script dapat dilakukan dengan menekan tombol add component pada tab inspector. Hal pertama yang perlu dilakukan adalah menambahkan object ARCamera pada scene, setelah itu tambahkan komponen baru pada object tersebut. Proses ini dapat dilihat pada gambar 11 .

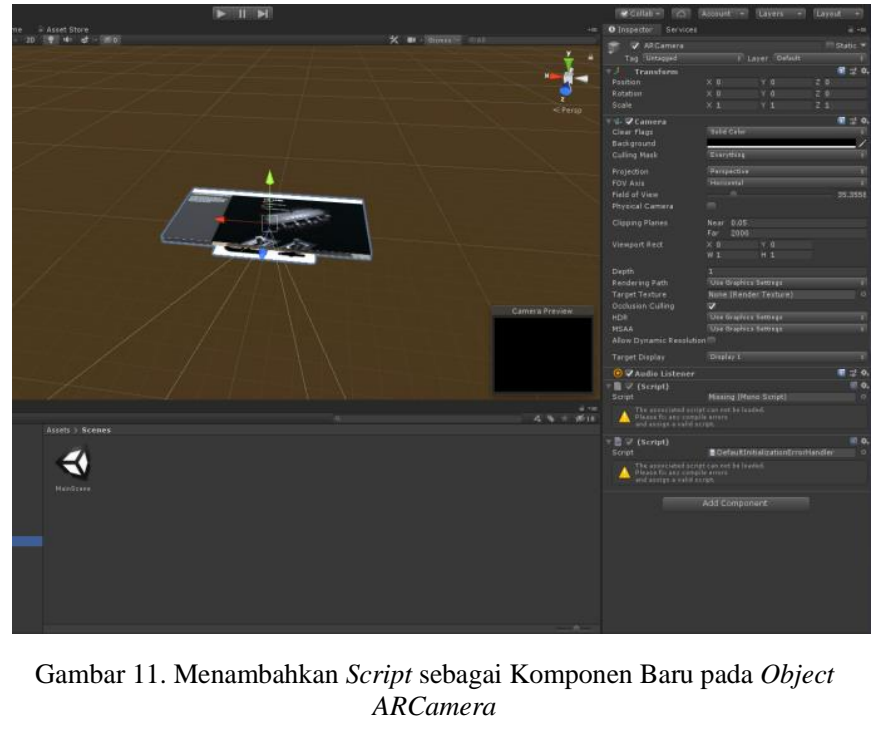

\section{IV.HASIL EKSPERIMEN DAN EVALUASI}

\section{A. Pointing Accuracy}

Pada penelitian ini dilakukan 3 percobaan untuk mengukur akurasi penunjuk gambar dan jarak maksimum antara smartphone dengan marker, dan untuk mengevaluasi ketahanan terhadap gerakan dan rotasi. digunakan laptop 1080p 120Hz 15,8 inci (Zephyrus GX501VIK) sebagai layar dan Galaxy Note 10 (Samsung) sebagai smartphone. Eksperimen dilakukan di ruangan gelap yang dirancang secara khusus.

Pada percobaan ini, untuk menirukan jarak posisi smartphone terhadap marker digunakan motor plotter $X Y$ untuk memindahkan smartphone dengan peningkatan jarak $70 \mathrm{~mm}$, sejajar dengan tepi layar laptop. Smartphone diposisikan 100-mm di atas layar. Hasil dari eksperimen ini divisualisasikan dengan menggunakan box plot yang dapat dilihat pada gambar 12 .

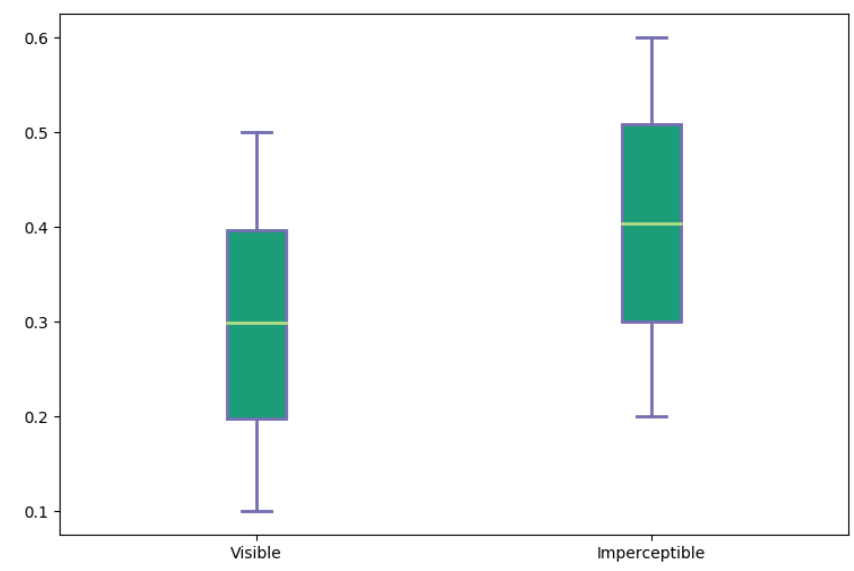

Gambar 12. Hasil percobaan 1 (pointing accuracy) 
TABEL I

Hasil PercobaAn PembacaAn MARKer

\begin{tabular}{|c|c|c|c|c|c|}
\hline Jenis Marker & $20 \%$ Terlihat & $40 \%$ Terlihat & $\begin{array}{c}60 \% \\
\text { Terlihat }\end{array}$ & $80 \%$ Terlihat & $100 \%$ Terlihat \\
\hline Spec-1 & Tidak Terbaca & Tidak Terbaca & Terbaca & Terbaca & Terbaca \\
\hline Spec-2 & Tidak Terbaca & Tidak Terbaca & $\begin{array}{c}\text { Tidak } \\
\text { Terbaca }\end{array}$ & Terbaca & Terbaca \\
\hline Spec-3 & Tidak Terbaca & Tidak Terbaca & $\begin{array}{c}\text { Tidak } \\
\text { Terbaca }\end{array}$ & Terbaca & Terbaca \\
\hline Spec-4 & Tidak Terbaca & Tidak Terbaca & Terbaca & Terbaca & Terbaca \\
\hline Spec-5 & Tidak Terbaca & Tidak Terbaca & Terbaca & Terbaca & Terbaca \\
\hline Hasil & $0 \%$ & $0 \%$ & $50 \%$ & $100 \%$ & $100 \%$ \\
\hline
\end{tabular}

Pada gambar 12, sumbu y menunjukan tingkat error yang didefinisikan sebagai jarak antara ground truth dan nilai yang diukur. Rata-rata kesalahan dengan penanda terlihat adalah $0,30 \mathrm{~mm}$ dan kesalahan maksimum adalah $0,5 \mathrm{~mm}$. Sebaliknya, median kesalahan dengan marker tak terlihat adalah 0,4 mm dan kesalahan maksimum 0,6 mm. Tidak ada perbedaan yang signifikan antara penanda yang terlihat dan tidak terlihat.

\section{B. Tingkat Deteksi pada Smartphone Bergerak}

Pada percobaan ini diukur tingkat deteksi, ketika smartphone bergerak. Smartphone dipasang pada motor slide linear listrik dan bergerak dengan kecepatan konstan, $140 \mathrm{~mm}$ di atas layar. Jarak bergerak dari titik awal diukur. Pada percobaan ini dilakukan 100 pengukuran pada setiap kecepatan dan menghitung tingkat deteksi. Gambar yang diuji menggunakan gambar yang sama dengan gambar yang digunakan pada percobaan 1 . Hasil eksperimen dapat dilihat pada gambar 13 .

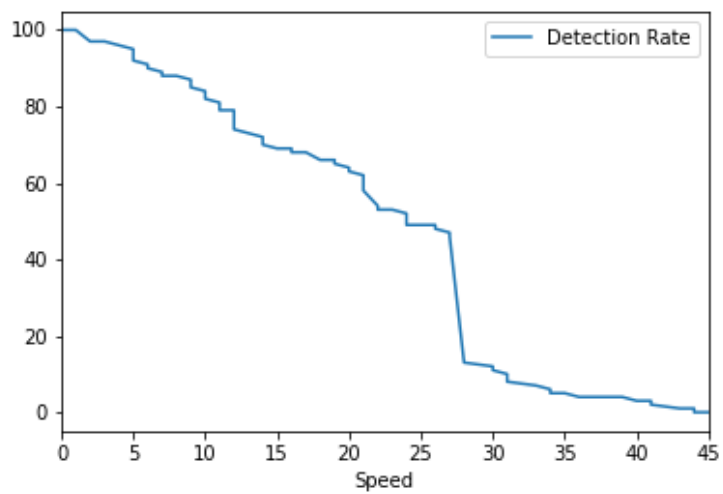

Gambar 13. Hasil percobaan 2 (tingkat deteksi terhadap pergerakan)

Jika diperhatikan pada gambar 13, marker tidak dapat dideteksi lebih dari $45 \mathrm{~mm} / \mathrm{s}$. Meskipun kinerja sistem tidak memuaskan ketika smartphone bergerak, hasil ini menyiratkan bahwa sistem dapat menahan guncangan kamera.

\section{Pengujian Pembacaan Marker}

Pengujian yang dilakukan adalah dengan melihat hasil pembacaan kamera terhadap marker yang terlihat pada jarak pandangnya. Pada pengujian ini dilakukan secara realtime menggunakan marker yang sudah dicetak. Pada tabel I dapat dilihat hasil percobaan yang dilakukan pada posisi marker yang tertutup pada persentase yang ditunjukan pada kolom tabel I.

\section{Survey Sample}

Sampel penelitian terdiri dari seratus kustomer yang dipilih secara acak dari dua lokasi showroom mobil yang berbeda. Para kustomer tersebut belum pernah melihat atau menggunakan teknologi $A R$ sebelumnya. Survey dilakukan dengan menggunakan hasil akhir yang dapat dilihat pada gambar 8. Karakteristik demografis kustomer tersebut diberikan pada Tabel II.

TABEL II

KARAKTERISTIK KUSTOMER

\begin{tabular}{|l|l|l|l|}
\hline Group & Laki-Laki & Perempuan & Total \\
\hline Experimental & 32 & 18 & 50 \\
\hline Control & 32 & 18 & 50 \\
\hline Total & $\mathbf{6 4}$ & $\mathbf{3 6}$ & $\mathbf{1 0 0}$ \\
\hline
\end{tabular}

Dalam penelitian ini, convenience sampling digunakan. Metode ini memungkinkan peneliti cepat dan mudah mengakses sampel. Selain itu, metode ini memungkinkan para peneliti untuk mengakses ukuran sampel besar [19]. Metode pengambilan sampel ini lebih disukai karena showroom mobil yang dipilih bersedia untuk berpartisipasi dalam penelitian ini.

\section{E. Sikap terhadap Penggunaan Aplikasi AR}

Dalam penelitian ini, skala yang dikembangkan oleh Küçük, Yılmaz, Baydaş dan Göktaş digunakan untuk mengukur sikap kustomer terhadap aplikasi $A R$ [20]. Skala ini terdiri dari 15 item yang mencerminkan 3 faktor: kepuasan, kecemasan dan kesediaan. Kepuasan berhubungan dengan pemikiran kustomer tentang apakah teknologi $A R$ mudah digunakan dan berguna untuk penjelasan spesifikasi mobil. Kesediaan mencerminkan 
keinginan kustomer untuk menggunakan teknologi AR. Jika tingkat kepuasan dan kesediaan kustomer tinggi, sikap kustomer terhadap teknologi

AR juga akan positif. Kecemasan berhubungan dengan keraguan tentang penggunaan teknologi $A R$ yang mungkin dimiliki kustomer. Ketika tingkat kecemasan tinggi, sikap kustomer terpengaruh secara negatif. Skala ini dinilai pada skala 5-Point-Likert, mulai dari 1 (Sangat Tidak Setuju) hingga 5 (Sangat Setuju) dan memiliki koefisien reliabilitas internal 0,83 .

\section{F. Data Analysis}

Dalam penelitian ini, analisis deskriptif dan prediksi dilakukan. Pertama, tiga nilai diidentifikasi sebagai outliers dan data ekstrem dihapus. Kemudian, statistik skewness dan kurtosis dikontrol untuk setiap variabel.

TABEL III

SIKAP DAN TINGKAT MENGERTINYA KUSTOMER

\begin{tabular}{|l|l|l|l|l|}
\hline Group & Group & $N$ & $M$ & $S D$ \\
\hline \multirow{3}{*}{ Sikap } & Experimental & 49 & 80.49 & 7.970 \\
\cline { 2 - 5 } & Control & 48 & 63.07 & 15.063 \\
\hline \multirow{2}{*}{$\begin{array}{l}\text { Tingkat } \\
\text { Mengerti }\end{array}$} & Experimental & 49 & 87.04 & 11.678 \\
\cline { 2 - 5 } & Control & 48 & 67.67 & 12.852 \\
\hline
\end{tabular}

TABEL IV

PENILAIAN 3 FAKTOR TERHADAP KUSTOMER

\begin{tabular}{|l|l|l|l|l|}
\hline Faktor & Min. & Max. & M & SD \\
\hline Kepuasan & 3.78 & 5.00 & 3.98 & .425 \\
\hline Kesediaan & 2.90 & 5.00 & 4.34 & .518 \\
\hline Kecemasan & 1.23 & 4.33 & 1.12 & .577 \\
\hline
\end{tabular}

Diamati bahwa data memiliki distribusi normal karena nilai-nilai ini antara -2 dan +2 . Sikap terdistribusi normal, dengan skewness -126 (SE = .266), dan kurtosis -557 (SE = .623). Dengan ini ditemukan beberapa poin penting yaitu:

a. Sikap dan tingkat mengertinya kustomer terhadap penjelasan spesifikasi dalam experimental dan control group. Hasil dapat dilihat pada tabel III.

b. Tabel III menunjukkan bahwa kustomer dalam experimental group memiliki tingkat sikap positif yang lebih tinggi terhadap penjelasan spesifikasi menggunakan $A R(\mathrm{M}=80.49, \mathrm{SD}=7.970)$ dan tingkat mengerti yang lebih tinggi $(\mathrm{M}=87.04, \mathrm{SD}=$ 11.678) daripada kustomer dalam control group.

c. Sikap kustomer dalam experimental group terhadap aplikasi AR. Hasil dapat dilihat pada tabel IV. Menurut hasil, kustomer senang menggunakan aplikasi $A R(\mathrm{M}=3.98, \mathrm{SD}=.425)$ dan kustomer bersedia untuk menggunakannya lagi $(\mathrm{M}=4,34, \mathrm{SD}$ $=$.518). Kustomer-kustomer ini juga tidak menunjukkan kecemasan saat menggunakan aplikasi $A R(\mathrm{M}=1,23, \mathrm{SD}=0,577)$.

\section{KESIMPULAN DAN SARAN}

\section{A. Kesimpulan}

Berdasarkan hasil perancangan dan pengujian terhadap software yang telah dibuat, maka dapat diambil kesimpulan sebagai berikut:

Perancangan pembuatan software Sistem Pengenalan Spesifikasi Mobil pada Showroom Menggunakan Teknologi Augmented Reality Berbasis Metode Haar-like features telah berhasil direalisasikan.

Sistem pendeteksi fitur menggunakan Haar-like ini memiliki tingkat akurasi dan ketahanan yang cukup dalam guncangan kamera sehari-harinya.

Kompleksitas gambar dan banyaknya sudut sangat mempengaruhi pembacaan data titik oleh Haar-like features.

Para kustomer senang dan ingin terus menggunakan aplikasi $A R$ di masa depan. Kustomer juga tidak menunjukkan tanda-tanda kecemasan saat menggunakan aplikasi $A R$. Selain itu, ditemukan bahwa tingkat mengerti dan sikap kustomer dalam experimental group menunjukkan korelasi positif.

\section{B. Saran}

Sebaiknya analisis disertakan dengan perbandingan dengan algoritma lain sehingga diketahui efektivas dari metode yang diajukan. Aplikasi sebaiknya dipasarkan secara realtime sehingga dapat diketahui performa yang sesungguhnya.

\section{UCAPAN TERIMA KASIH}

Terima kasih diucapkan sebesar - besarnya kepada para pengajar dan staf Fakultas Teknologi Informasi dan Fakultas Teknik, Program Studi Magister Ilmu Komputer dan Prodi Sistem Komputer Universitas Kristen Maranatha Bandung atas dukungan dan bantuannya dalam penyusunan makalah hasil penelitian ini.

\section{DAFTAR PUSTAKA}

[1] J. Sanjaya and M. Ayub, "Augmentasi Data Pengenalan Citra Mobil Menggunakan Pendekatan Random Crop, Rotate, dan Mixup," Jurnal Teknik Informatika dan Sistem Informasi, vol. 6, no. 2, pp. 311-322, 2020.

[2] A. Luo, F. An, X. Zhang, and H. J. Mattausch, "A HardwareEfficient Recognition Accelerator Using Haar-Like Feature and SVM Classifier," IEEE Access, vol. 7, pp. 14472-14487, 2019.

[3] D. L. Gomes et al., "Augmented visualization using homomorphic filtering and Haar-based natural markers for power systems substations," (in en), Computers in Industry, vol. 97, pp. 67-75, 2018.

[4] T. Khan, K. Johnston, and J. Ophoff, "The Impact of an Augmented Reality Application on Learning Motivation of Students," (in en), Advances in Human-Computer Interaction, vol. 2019, pp. 1-14, 2019.

[5] D. Sahin and R. M. Yilmaz, "The effect of Augmented Reality Technology on middle school students' achievements and attitudes towards science education," (in en), Computers \& Education, vol. 144, p. 103710, 2020.

[6] C. Shen, P. Wang, S. Paisitkriangkrai, and A. van den Hengel, "Training Effective Node Classifiers for Cascade Classification," (in 
en), International Journal of Computer Vision, vol. 103, no. 3, pp. 326-347, 2013.

[7] N. Conway, A. Soro, R. Brown, and S. Turkay, "Exploring Uses of Augmented Reality in Participatory Marketing," in Extended Abstracts of the 2019 CHI Conference, 2019, Glasgow, Scotland Uk: ACM Press, pp. 1-6.

[8] J. Glover, Unity 2018 augmented reality projects: build four immersive and fun AR applications using ARKit, ARCore, and Vuforia. Birmingham Mumbai: Packt, 2018, p. 346.

[9] M. C. tom Dieck and T. Jung, Eds. Augmented Reality and Virtual Reality: The Power of $A R$ and VR for Business (Progress in IS). Cham: Springer International Publishing (in en), 2019.

[10] J. Y. C. Chen and G. Fragomeni, Eds. Virtual, Augmented and Mixed Reality: Interaction, Navigation, Visualization, Embodiment, and Simulation: 10th International Conference, VAMR 2018, Held as Part of HCI International 2018, Las Vegas, NV, USA, July 15-20, 2018, Proceedings, Part I (Lecture Notes in Computer Science). Cham: Springer International Publishing (in en), 2018.

[11] I. Landesa-Vazquez and J. L. Alba-Castro, "The Role of Polarity in Haar-like Features for Face Detection," in 2010 20th International Conference on Pattern Recognition (ICPR), 2010, Istanbul, Turkey: IEEE, pp. 412-415.

[12] R. T. Azuma, "A Survey of Augmented Reality," (in en), Presence: Teleoperators and Virtual Environments, vol. 6, no. 4, pp. 355-385, 1997.

[13] P. Mealy, Virtual \& augmented reality for dummies, 1st edition ed. Indianapolis, IN: John Wiley and Sons, 2018.
[14] M. Lanham, Learn ARCore: fundamentals of Google ARCore : learn build augmented reality apps for Android, Unity, and the web with Google ARCore 1.0. (in English), 2018.

[15] R. Fonseca, W. Creixell, J. Maiguashcaz, and V. Ruedaay, "Object detection on aerial image using cascaded binary classifier," in 2016 IEEE Applied Imagery Pattern Recognition Workshop (AIPR), 2016, Washington, DC, USA: IEEE, pp. 1-6.

[16] P. Viola and M. Jones, "Rapid object detection using a boosted cascade of simple features," in 2001 IEEE Computer Society Conference on Computer Vision and Pattern Recognition. CVPR 2001, 2001, vol. 1, Kauai, HI, USA: IEEE Comput. Soc, pp. I-511I-518.

[17] P. Viola and M. Jones, "Robust real-time face detection," in Eighth IEEE International Conference on Computer Vision, 2001, vol. 2 , Vancouver, BC, Canada: IEEE Comput. Soc, pp. 747-747.

[18] W. R. Sherman and A. B. Craig, Understanding virtual reality: interface, application, and design (Morgan Kaufmann series in computer graphics and geometric modeling). Amsterdam; Boston: Morgan Kaufmann Publishers, 2003, p. 582.

[19] Z. Ozdilek, S. Okumus, and K. Doymus, "The Effects Of Model Supported Cooperative And Individual Learning Methods On Prospective Science Teachers' Understanding Of Solutions," Journal of Baltic Science Education, vol. 17, no. 6, p. 945, 2018.

[20] S. Küçük, R. Yilmaz, Ö. Baydas, and Y. Göktas, "Augmented reality applications attitude scale in secondary schools: Validity and reliability study," Egitim ve Bilim, vol. 39, no. 176, 2014. 